\title{
KEANEKARAGAMAN JENIS KERANG (KELAS BIVALVIA) DI PERAIRAN PULAU SIBU KECAMATAN OBA UTARA KOTA TIDORE KEPULAUAN
}

\author{
Wirda Az. Umagap dan Lintal Muna \\ Dosen Program Studi Tadris Biologi Fakultas Tarbiyah dan Ilmu Keguruan \\ IAIN Ternate \\ Email: widhadrakel@gmail.com; muna.lintal@gmail.com \\ Manuscript received: 16-09-2018, Revision accepted: 05-11-2018
}

\begin{abstract}
Abstrak
Menurut Pusat Penelitian Oseanografi LIPI, di Perairan Ternate dan Tidore serta perairan sekitarnya memiliki kekayaan hayati laut yang tinggi dan dapat dipastikan bahwa perairan ini merupakan bagian dari pusat kekayaan keanekaragaman laut dunia. Pulau Sibu merupakan pulau yang terletak di Desa Guraping Kecamatan Oba Utara Kabupaten Kota Tidore Kepulauan. Letak geografis Pulau Sibu adalah 043'28"LU127³4'50"BT. Kondisi geografisnya yang dikelilingi oleh tumbuhan mangrove dan karang memungkinkan pulau ini kaya akan biota laut, salah satunya adalah kerang yang dalam sistematikanya tergolong ke dalam kelas Bivalvia. Selain itu, pulau in oleh Pemerintah Kota Tidore Kepulauan dijadikan sebagai salah satu tempat wisata. Perlu adanya monitoring tentang kondisi biota laut yang berada di kawasan Pulau tersebut. Tujuan dari penelitian ini adalah untuk mengetahui keanekaragaman jenis dan dominasi kerang (kelas Bivalvia) di Perairan Pulau Sibu Kecamatan Oba Utara Kabupaten Kota Tidore Kepulauan. Penelitian ini merupakan penelitian deskriptif kuantitatif, yang berlokasi di Perairan Pulau Sibu Desa Guraping Kecamatan Oba Utara Kabupaten Kota Tidore Kepulauan. Adapun waktu penelitian yaitu selama 3 bulan mulai dari Agustus hingga Oktober 2016. Penelitian ini menggunakan metode line transek, dengan panjang transek/lintasan sepanjang $50 \mathrm{~m}$ dan berjumlah 2 lintasan. Masing-masing lintasan terdiri dari 5 kuadran, dengan ukuran masing-masing kuadran $2 \times 2 \mathrm{~m}^{2}$. hasil penelitian dianalisis dengan menggunakan indeks keanekaragaman jenis $\left(\mathrm{H}^{\prime}\right)$ Shannon Weinner, dan nilai dominansi $(\mathrm{C})$. Hasil penelitian menunjukkan bahwa keanekaragaman jenis kerang di perairan Pulau Sibu tergolong rendah dengan indeks keanekaragaman jenis ratarata pada lintasan I yaitu 0,23 dan lintasan II 0,28. Nilai dominansi menunjukkan bahwa Tridacna maxima mendominasi di perairan Pulau Sibu dengan nilai dominansi pada lintasan I adalah 0,67 dan lintasan II 0,53 dan tergolong dominansi sedang.
\end{abstract}

Kata Kunci : Bilvalvia, Keanekaragaman Jenis, Pulau Sibu

\section{PENDAHULUAN}

Menurut Pusat Penelitian Oseanografi LIPI bahwa di Perairan Ternate, Tidore dan sekitarnya memiliki kekayaan hayati laut yang tinggi dan dapat dipastikan bahwa perairan ini merupakan bagian dari pusat kekayaan keanekaragaman laut dunia (Pusat Penelitian Oseanografi, 2012). Berdasarkan data dari Pusat Oseanografi LIPI menunjukkan bahwa Terumbu karang di perairan Ternate, Tidore dan sekitarnya memiliki keanekaragaman karang yang relatif tinggi. Setidaknya berhasil dijumpai sebanyak 144 jenis, yang termasuk dalam 44 marga dan 17 suku. Secara keseluruhan, ditemukan 50 jenis mangrove sejati dan asosiasinya dimana 28 jenis diantaranya merupakan mangrove sejati dan 22 jenis mangrove asosiasi. Keanekaragaman jenis mangrove tergolong rendah dengan didominasi oleh Sonneratia alba, $S$. caseolaris dan R. apiculata. Akan tetapi, hutan mangrove di Pulau Ternate, Tidore dan pulau- 
pulau di sekitarnya memiliki total jumlah karbon tersimpan rata-rata $865,77 \pm 1302,82$ ton per hektar (Pusat Penelitian Oseanografi, 2012).

Pulau Sibu merupakan salah satu pulau yang memiliki daya tarik tersendiri sebagai kawasan ekowisata dengan hamparan pasir putih dan termasuk pulau tidak berpenghuni. Secara administratif pulau Sibu terletak di Desa Guraping Kecamatan Oba Utara Kota Tidore Kepulauan, dan secara geografis berada pada koordinat $0^{\circ} 43^{\prime} 28^{\prime \prime} \mathrm{LU} 127^{\circ} 34^{\prime} 50^{\prime \prime} \mathrm{BT}$. Kondisi geografisnya dikelilingi oleh tumbuhan mangrove dan karang, memungkinkan pulau ini kaya akan biota laut, salah satunya adalah kerang yang dalam sistematikanya tergolong kedalam kelas Bivalvia.

Kerang merupakan hewan laut yang tidak bertulang belakang (invertebrata) dari kelompok hewan bertubuh lunak (Mollusca) yang memiliki 2 cangkang keras sebagai pelindung tubuhnya. Habitat utama kerang yakni di perairan pantai yang memiliki pasir berlumpur hingga kedalaman \pm 4-6 meter dan perairan yang relatif tenang. Selain itu, kerang dapat juga ditemukan di daerah muara, hutan mangrove serta padang lamun. Pada umumnya, kerang hidup mengelompok dan terbenam dalam pasir berlumpur (Tim Perikanan WWF Indonesia, 2015). Beberapa kerang hidup pada substrat yang lebih keras seperti lempung, kayu, atau batu.

Beberapa manfaat kerang, yaitu dagingnya dapat dikonsumsi sebagai sumber protein, cangkangnya dimanfaatkan sebagai perhiasan, bahan kerajinan tangan, penghasil mutiara, serta pemanfaatan modern juga menjadikan kerang-kerangan sebagai biofilter terhadap polutan (Bivalvia, 2016). Manfaat lain, misalnya kerang darah merupakan sumber mineral yang berfungsi sebagai antioksidan, diantaranya adalah $\mathrm{Zn}, \mathrm{Fe}$ dan $\mathrm{Cu}$. Selain itu juga merupakan sumber Ca (Nurjanah, Zulhamsyah dan Kustiyariyah, 2005).

Pulau Sibu adalah salah satu pulau yang oleh pemerintah Kota Tidore Kepulauan dijadikan sebagai salah satu obyek wisata yang pengelolaannya diserahkan kepada karang taruna setempat. Sebagai obyek wisata, diperlukan adanya pengelolaan yang tepat dan monitoring terkait dengan jenis biota yang hidup di pulau tersebut. Mengingat belum adanya data yang lengkap terkait dengan biota laut penghuni Pulau Sibu khususnya adalah kerang, maka perlu adanya pengambilan data tentang keanekaragan jenis kerang (kelas Bivalvia). Dengan adanya data yang lengkap, diharapkan masyarakat dapat mempromosikan obyek wisata tersebut serta dapat menjaga biota laut dengan baik agar kelestariannya tetap terjaga.

Berdasarkan alasan tersebut di atas, maka peneliti bermaksud untuk melakukan penelitian tentang keanekaragaman jenis kerang (kelas Bivalvia) di perairan Pulau Sibu Kecamatan Oba Utara Kabupaten Kota Tidore Kepulauan dan jenis kerang apa yang mendominasi di lokasi tersebut.

\section{METODE PENELITIAN}

Penelitian ini merupakan penelitian deskriptif kuantitatif, yang berlokasi di perairan Pulau Sibu, Desa Guraping Kecamatan Oba Utara Kabupaten Kota Tidore Kepulauan. Adapun waktu penelitiannya yaitu selama 3 bulan, mulai Agustus hingga Oktober 2016. Beberapa alat yang digunakan dalam penelitian ini adalah, meteran rol, kantung sampel, kertas label, buku identifikasi, alt tulis, termometer, hand refraktometer, DO meter, sarung tangan, tali rafia, penjepit, dan kamera digital. Adapun bahan-bahan yang digunakan dalam penelitian ini adalah seluruh spesies kerang (kelas Bivalvia) yang terdapat di perairan Pulau Sibu Kecamatan Oba Utara Kabupaten Kota Tidore Kepulauan yang terdapat dalam kuadran, serta larutan formalin $4 \%$. 
Untuk menghitung Indeks Keanekaragaman, digunakan indeks punya Shannon dan Weinner menurut Ludwig dan Reynold (1989) sebagai berikut:

$$
H^{\prime}=-\sum\left[\frac{n i}{N}\right] \operatorname{Ln}\left[\frac{n i}{N}\right]
$$

Keterangan:

$\mathrm{H}^{\prime}=$ Indeks keanekaragaman jenis

ni = Jumlah individu spesies ke-1

$\mathrm{N}$ = Jumlah total seluruh spesies

Kriteria:

Jika $\mathrm{H}^{\prime} \leq 1$, maka keanekaragaman jenis rendah

$1<\mathrm{H}^{`}<3$, maka keanekaragaman jenis sedang

$\mathrm{H}^{\prime} \geq 3$, maka keanekaragaman jenis tinggi

Untuk menghitung Indeks Dominasi digunakan formula Odum (1979) dalam Melati, 1971) dengan rumus sebagai berikut:

$$
C=\sum\left(\frac{n i}{N}\right)^{2}
$$

Keterangan:

Kriteria :

$$
\begin{aligned}
& \mathrm{C}=\text { Indeks Dominansi Jenis } \\
& \mathrm{ni}=\text { Jumlah individu spesies } \\
& \mathrm{N}=\text { Jumlah total individu }
\end{aligned}
$$

$0,00<\mathrm{C} \leq 0,50:$ Rendah

$0,50<\mathrm{C} \leq 0,75:$ Sedang

$0,75<\mathrm{C} \leq 1,00$ : Tinggi

\section{HASIL DAN PEMBAHASAN}

a. Komposisi Jenis-Jenis Kerang

Berdasarkan hasil pengamatan di perairan Pulau Sibu ditemukan jumlah individu sebanyak 30 individu yang dikategorikan menjadi 2 spesies dalam 1 famili Tridacnidae, dengan menggunakan kunci identifikasi tingkat famili sebagai berikut:

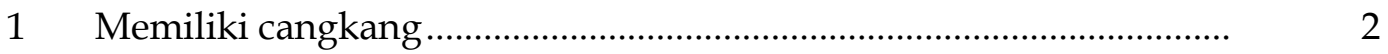

$2 \quad$ Memiliki 2 cangkang....................................................................... $\quad 30$

30 Bagin umbo cangkang tidak bersifat Terminal, tidak terdapat lapisan

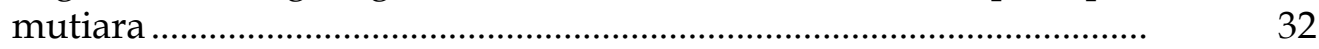

32 Tepi dorsal bagian anterior dan / atau posterior cangkang tidak membentuk sayap panjang ................................................................... 35

35 Umbo tidak membentuk auricle atau cuping...................................... 37

37 Cangkang tidak memiliki bekas perlekatan otot aduktor tunggal yang jelas dengan gigi hinge yang membentuk huruf ' $\mathrm{V}$ '

38 Cangkang berukuran besar atau sangat besar, memiliki rib-rib radial yang besar pula berjumlah kurang dari 15, kadang memiliki sisik yang besar, umumnya memiliki lubang bisus

Tridacnidae 
Hasil identifikasi dikelompokkan ke dalam famili Tridacnidae, sebagaimana ditunjukkan pada Tabel 1 berikut.

Tabel 1. Komposisi Jenis-jenis kerang di Perairan Pulau Sibu Kecamatan Oba Utara

\begin{tabular}{cccc}
\hline No & Kelas & Famili & Spesies \\
\hline 1. & Bivalvia & Tridacnidae & Tridacna crocea \\
& & & Tridacna maxima \\
\hline
\end{tabular}

Berdasarkan hasil identifikasi bahwa jenis kerang yang banyak ditemukan ternyata dari jenis Tridacna maxima dibanding jenis Tridacna crocea. Keanekaragaman jenis kerang di perairan Pulau Sibu lebih banyak didiami oleh jenis Tridacna maxima karena jenis ini lebih banyak ditemukan pada habitat karang atau substrat berpasir, dan di perairan yang jernih.

Beberapa hasil penelitian menunjukkan bahwa populasi kima (kerang besar) di alam didominasi oleh spesies-spesies kecil seperti Tridacna crocea dan T. maxima, sedangkan spesies besar seperti T. derasa, T. squamosa. Hipoppus hipoppus dan H. porcellanusi sudah sangat jarang ditemukan. Bahkan untuk spesies terbesar yakni T. gigas sudah tidak ditemukan lagi di beberapa tempat. Menurunnya populasi kima di alam, antara lain disebabkan oleh: 1) Fishing. Pengambilan / pemanenan kima secara langsung di alam merupakan faktor utama penyebab menurunnya populasi kima di alam secara cepat, didorong oleh kebutuhan penduduk di sekitar pantai; kebutuhan eksport; 2) Penyakit dan parasit. Penyakit dan parasit pada kima disebabkan oleh Vibrio sp., Aeromonas sp., Perkinsus sp; 3) Predasi. Terutama dilakukan oleh snail (Chicoreus ramosus dan Cymatium muricinum), hermit crab (Dardanus deformis), dan sea bream (Monotaxis granoculis); 4) Faktor lingkungan. Termasuk di dalamnya adalah suhu dan salinitas; serta 5) Anthropogenic. Termasuk di dalamnya adalah polusi (Ambariyanto, 2007).

\section{b. Deskripsi Jenis-jenis Kerang}

Kerang yang diperoleh dari hasil penelitian, kemudian diidentifikasi menggunakan kunci identifikasi famili untuk filum Moluska dan diperoleh hasil sebagai berikut.

\section{Tridacna crocea}

Kelas Bivalvia, Famili Tridacnidae, jenis ini memiliki cangkang berbentuk oval dan dapat lebarnya mencapai $30 \mathrm{~cm}$. Cangkang tebal, keras, berwarna putih dan mengapur dengan tepi yang bergelombang. Permukaan cangkang mempunyai garis-garis radial yang tidak beralur dalam. Lempeng-lempeng pada garis-garis radial sangat tipis dan tersusun konsentris secara rapat. Lubang tempat benang bisus keluar besar dan bergerigi. Warna mantel abu-abu kehitaman dengan bintik-bintik hijau muda. Hidup membenamkan diri pada karang atau pasir, pada perairan yang jernih.

\section{Tridacna maxima}

Kelas Bivalvia, Famili Tridacnidae, jenis ini mempunyai cangkang berbentuk memanjang dan agak oval, lebar dapat mencapai $50 \mathrm{~cm}$. Cangkang keras, tebal, berwarna putih dan mengapur dengan tepi cangkang bergelombang. Pada permukaan cangkang terdapat garis-garis radial yang beralur dalam dengan lempeng-lempeng tajam dan tebal yang tersusun konsentris. Lempeng-lempeng tersebut berukuran lebih pendek serta tersusun lebih rapat dari pada susunan lempeng-lempeng T. squamosa. Lubang tempat benang bisus keluar lebih kecil dari pada yang dimiliki T. crocea. Hidup membenamkan diri pada karang-karang atau pasir, pada perairan yang jernih. 


\section{c. Keanekaragaman Jenis Kerang}

Keanekaragaman biota dalam suatu perairan sangat tergantung pada banyaknya spesies dalam komunitasnya. Semakin banyak jenis yang ditemukan, maka keanekaragaman akan semakin besar, meskipun nilai ini sangat tergantung dari jumlah inividu masing-masing jenis (Wilhm and Doris. 1986). Pendapat ini juga didukung oleh Krebs yang menyatakan bahwa semakin banyak jumlah anggota individunya dan merata, maka indeks keanekaragaman juga akan semakin besar (Krebs, 1997 dalam Melati, 2007).

Indeks keanekaragaman $\left(\mathrm{H}^{\prime}\right)$ merupakan suatu angka yang tidak memiliki satuan dengan kisaran 0-3. Tingkat keanekaragaman akan tinggi jika nilai $\mathrm{H}^{\prime}$ mendekati 3, sehingga hal ini menunjukkan kondisi perairan baik. Sebaliknya jika nilai $\mathrm{H}^{\prime}$ mendekati 0, maka keanekaragaman rendah dan kondisi perairan dapat dikatakan kurang baik (Odum, 1993 dalam Melati, 2007).

Tabel 2. Indeks Keanekaragaman Jenis Kerang di Perairan Pulau Sibu

\begin{tabular}{llcc}
\hline \multirow{2}{*}{ No. } & Nama Spesies & \multicolumn{2}{c}{ Indeks Keanekaragaman Jenis $\left.\mathbf{( H}^{\prime}\right)$} \\
\cline { 2 - 3 } 1. & Tridacna crocea & Lintasan I & Lintasan II \\
2. Tridacna maxima & 0,31 & 0,35 \\
Total $\mathbf{H}^{\prime}$ & 0,15 & 0,22 \\
\multicolumn{2}{c}{ Rata-rata } & $\mathbf{0 , 4 6}$ & $\mathbf{0 , 5 7}$ \\
\hline
\end{tabular}

\section{d. Dominansi Kerang}

Tabel 3. Nilai Dominansi Kerang di Perairan Pulau Sibu

\begin{tabular}{llcc}
\hline \multirow{2}{*}{ No. } & \multirow{2}{*}{ Nama Spesies } & \multicolumn{2}{c}{ Dominansi (C) } \\
\cline { 2 - 3 } 1. & Tridacna crocea & Lintasan I & Lintasan II \\
2. & Tridacna maxima & 0,03 & 0,07 \\
Total Dominansi $(\mathbf{C})$ & 0,67 & 0,53 \\
\hline
\end{tabular}

Penelitian tentang pemijahan Kima tahun 2008 di laboratorium UPT Loka Konservasi Biota Laut Tual mendapatkan bahwa kima jenis $T$. crocea memijah spontan pada bulan Mei (Edward; Kusnadi ; Hernawan; \& Triandiza. 2008). T. maxima dari perairan Pulau Anae Guam memiliki musim pemijahan mulai bulan November sampai dengan Maret dengan tingkat kematangan gonad tinggi dan siap memijah pada periode bulan Februari. Di Palau, spesies kima Hippopus hippopus memijah pada bulan Juni dan T. crocea pada bulan Juli.

\section{e. Parameter Lingkungan Perairan Pulau Sibu}

Pengukuran parameter fisika dan kimia perairan dimaksudkan untuk melihat pengaruh faktor-faktor fisika dan kimia air laut (berdasar Keputusan Menteri Negara Lingkungan Hidup, 2016).

Tabel 4. Perbandingan Parameter Fisika dan Kimia Perairan Pulau Sibu dengan Baku Mutu Air Laut untuk Biota Laut

\begin{tabular}{lcc}
\hline Parameter & Ukuran & Baku mutu air laut untuk biota laut \\
\hline Suhu air laut & $30,76^{\circ} \mathrm{C}$ & $28-32^{\circ} \mathrm{C}$ \\
pH air & 7,70 & $7-8,5$ \\
Salinitas & $35,9 \mathrm{ppt}$ & $33-34 \mathrm{ppt}$ \\
DO air & $5,87-6 \mathrm{mg} / \mathrm{l}$ & $>5$ \\
\hline
\end{tabular}


Jika dibandingkan dengan baku mutu air laut untuk biota laut yang ditetapkan oleh Menteri Negara Lingkungan Hidup Nomor 51 Tahun 2004, maka faktor kimia berupa salinitas yang melebihi ketentuan dengan ukuran 35,9 ppt dari ketentuan 33-34 ppt. Hal ini jelas mempengaruhi kehidupan kerang. Dalam hal ini, salinitas akan berpengaruh pada pengaturan ion-ion internal, yang secara langsung memerlukan energi untuk transpor aktif ion-ion guna mempertahankan lingkungan internal. Hal ini sangat berpengaruh pada proses fisiologis yang dapat berakibat pada mortalitas kima (Susiana, Andi Niartiningsih dan Muh. Anshar Amran, 2016).

\section{KESIMPULAN}

Berdasarkan hasil yang diperoleh, maka dapat disimpulkan bahwa:

1. Keanekaragaman jenis kerang di perairan Pulau Sibu tergolong rendah dengan indeks keanekaragaman jenis pada lintasan I yaitu 0,46 dan lintasan II 0,57.

2. Nilai dominansi menunjukkan bahwa Tridacna maxima mendominasi di perairan Pulau Sibu dengan nilai dominansi pada lintasan I adalah 0,67 dan lintasan II adalah 0,53 dan tergolong dominansi sedang.

\section{DAFTAR PUSTAKA}

Pusat Penelitian Oseanografi. 2012. Ekosistem Pesisir Ternate, Tidore dan Sekitarnya, Provinsi Maluku Utara. Pusat Penelitian Oseanografi LIPI Jakarta.

Tim Perikanan WWF Indonesia. 2015. Better Management Practices: Perikanan Kerang Panduan Penangkapan dan Penanganan, Edisi I, Jakarta: WWF-Indonesia, 2015

Suwignyo, Sugiarti, dkk. 2005. Avertebrata Air Jilid 1. Penebar Swadaya. Jakarta

Nurjanah, Zulhamsyah dan Kustiyariyah. 2005. Kandungan Mineral dan Proksimat Kerang Darah (Anadara granosa) Yang Diambil Dari Kabupaten Boalemo, Gorontalo. Buletin Teknologi Hasil Perikanan, Vol. VIII No. 2.

J.W. Nybakken. 1992. Biologi Laut: Suatu Pendekatan Ekologis, Alih Bahasa Oleh: H.M. Eidman. PT. Gramedia. Jakarta

Kasijan Romimohtarto dan Sri Juwana. 2009. Biologi Laut: Ilmu Pengetahuan Tentang Biota Laut, Edisi Revisi, Cet. 4, Djambatan. Jakarta.

Susiana, Andi Niartiningsih dan Muh. Anshar Amran. 2016. Hubungan Antara Kesesuaian Kualitas Perairan dan Kelimpahan Kima (Tridacnidae) di Kepulauan Spermonde, Fakultas Ilmu Kelautan dan Perikanan Universitas Hasanuddin Makassar.

Keputusan Menteri Negara Lingkungan Hidup Nomor 51 Tahun 2004 tentang Baku Mutu Air Laut.

Ludwig dan Reynold. 1989. Statistik Ekologi A Primer, Of Methode and Computing A. Willey Intercience, New York.

Odum, EP. 1971. Fundamental Ekologi. Universitas Gajah Mada Press, Yogyakarta.

Melati, F. Fachrul. 2007. Metodologi Sampling Bioekologi, Cet 1. Bumi Aksara. Jakarta.

J. L. Wilhm and T.C. Doris. 1986. Biologycal Parameter for Water Quality Criteria. Bio. Science: 18 